\title{
Corporate investment and bank-dependent borrowers during the recent financial crisis
}

\author{
Andra Buca and Philip Vermeulen \\ Directorate General Research \\ Monetary Policy Research Division \\ European Central Bank
}

This version: 13 February 2012

\begin{abstract}
This paper provides empirical evidence on the causal role of bank credit in explaining the collapse in corporate investment during the recent financial crisis. Using annual balance sheet data over the period 2000-2009 for Germany, France, Italy, Spain, Belgium and Portugal we compare the role of bank credit versus other types of credit for corporate investment during different episodes. We distinguish between investment boom years, investment downturn years and the investment collapse of 2009. We show that firm investment became highly sensitive to bank debt during the investment collapse of 2009 . During the crisis, higher bank debt leverage of firms is associated with reduced investment. The effects we find are quite sizeable. This contrasts with an absence of bank credit effects before the crisis and contrasts further with the absence of effects of other credit during the crisis. The effects of bank debt are largest for small and medium sized firms. We also find evidence that the effects are restricted to the South of Europe (Italy, Portugal, Spain). Our finding lends support to the view that banks credit supply was restricted during the recent financial crisis leading to real effects.
\end{abstract}

Key words: financial crisis, credit crunch, financial accelerator, bank-lending channel JEL:E22, E44

We benefited from discussions with Oreste Tristani and Gianni Lombardo. Helpful comments were received from Steven Ongena. Any remaining errors are solely ours. Corresponding author: Email:philip.vermeulen@ecb.europa.eu. DG-Research, ECB, Kaiserstrasse,29. 60311 Frankfurt am Main, Germany. The views expressed in this paper only reflect those of the authors. They do not necessarily reflect the views of the European Central Bank. 


\section{Introduction}

The recent financial crisis has renewed research interest in the role that credit plays in the propagation of shocks over the business cycle. In the literature, alternative models of a credit-channel operating have been proposed. The financial accelerator (Bernanke, Gertler, Gilchrist(1996)) states that fluctuations in net worth of borrowers lead to fluctuations in real activity. In the presence of credit-market imperfections, changes in net worth of borrowers are associated with endogenous movements in agency costs of borrowing, which lead to real effects on spending. The bank lending channel (Bernanke and Blinder (1988)) posits that shocks to bank balance sheets (such as monetary policy shocks) can influence the supply of bank-intermediated credit. If bank credit is special for at least some borrowers in the economy, these shifts will have real effects on the spending of those bank-dependent borrowers. Clearly, both channels are not mutually exclusive. They can operate either independently or jointly.

The recent financial crisis forms an ideal research ground to reopen the investigation upon the importance of both channels. The 2007-09 recession in the US and the 2008-09 recession in the Euro area coincided with a widespread financial crisis in which bank balance sheets were affected. The financial crisis arguably started as a sub-prime mortgage crisis in 2007 leading to large bank write-offs. ${ }^{1}$ Bank losses related to mortgage instruments gradually turned into a liquidity crisis for banks. Market access of banks was severely hampered after the Lehman event as creditors to banks were uncertain where serious losses would pop up. On both sides of the Atlantic, banks had to be rescued in this period. ${ }^{2}$

Considering the occurrence of large shocks to the banking system, this period should provide an ideal testing ground for the investigation of credit-channel effects, which will be our main focus in this paper. We provide new evidence on how shocks to the banking sector are propagated into the real economy. The aim of this paper is to investigate whether credit channel effects were important for the behavior of corporate investment during the financial crisis. More precisely we analyze the investment collapse that occurred in the euro area in 2009. In 2009 aggregate fixed capital formation in the euro area dropped by almost 12 percent. This drop is by a large margin the biggest drop on the historical record for the euro area.

Our empirical analysis shows that bank loans became an important explanatory variable for corporate investment in 2009. Firms that entered the year with a higher bank

\footnotetext{
${ }^{1}$ A more detailed account on what happened in the financial sector is provided in Brunnermeier (2009).

${ }^{2}$ For instance, in Germany IKB bank, several landesbanken and commercial banks had to be rescued by reorganization, merger and/or government guarantees and loans. In Belgium Fortis bank was partially nationalized in October 2008. The Irish banking system was almost completely nationalized.
} 
debt leverage reduced investment more than firms that entered with a lower bank debt leverage. We also compare this behavior to earlier downturns. We find that bank debt leverage of firms are not important in earlier downturns. In addition we show that small and medium sized firms, which we identify as bank-dependent borrowers, were sensitive to bank loans in 2009 whereas large firms were not. Given the large magnitude of the fall in investment and its importance for the aggregate business cycle in this period, we consider that our study is relevant in understanding the magnitude and nature of the output loss during the financial crisis and the role of bank credit supply in the propagation of shocks.

We derive our results from a harmonized panel dataset of aggregated balance sheet data of manufacturing firms, for different industries and size classes coming from 6 euro area countries (Germany, France, Italy, Spain, Belgium, Portugal). For each 2-digit industry in every country we construct industry-level investment and indebtedness of small, medium and large firms separately. Our database is similar to the Quarterly Financial Report in the US, with that difference that we only have annual data.

We draw inferences from investment regressions containing bank debt and total debt as two separate explanatory variables. We make this distinction in order to separate the credit channel effects operating through the financial accelerator and the bank lending channel. An important part of our argument is that in order to investigate the role of bank debt one has to also control for general indebtedness. The reason is the following. Imagine one finds that firms during the investment collapse of 2009 with high bank indebtedness invested less than firms with low bank indebtedness. This result is consistent with two clearly different propagation mechanisms during the financial crisis. First it is consistent with the idea that banks reduced the supply of credit or increased lending standards, where the ultimate source of the real effect are shocks coming from the banking sector. These shocks are then propagated to bank dependent borrowers.

Alternatively, it is also consistent with the financial accelerator channel, which puts the source at the firm balance sheet. Namely that firms with low collateralizeable net worth (i.e. high financial leverage) see their external premium rise more during downturns as they can post less valuable collateral. In other words, high bank indebtedness could simply proxy for high financial leverage and therefore a high sensitivity to the availability of collateral on the firm balance sheet. To distinguish between those two stories, we perform regressions in which we control for total financial leverage of the firm. By total financial leverage we mean, as in Rajan and Zingales (1995), the ratio of debt (both short and long term) to total assets (therefore debt includes all other debt besides bank debt). If reduced investment is simply due to a collateral channel, the source of debt should be irrelevant. Otherwise said, highly financially levered firms should see spending go down. However we find that it is only bank debt that is important, indicating that indeed the 
banking crisis provided an impetus for a bank-lending channel in reducing investment.

We further check whether the effects of bank debt were equally spread in the economy. We find unequal effects across two dimensions. Consistent with a flight to quality or a higher bank dependence of certain borrowers we find that the investment of small and medium sized corporations during the 2009 collapse was a function of bank indebtedness whereas large firm investment seems to be unaffected by bank indebtedness. This suggests that large firms have easier substitution possibilities in their sources of external finance than small firms. In addition we find that the effects are only present in the South of Europe (Spain, Portugal and Italy). This seems consistent with the fact that the South of Europe was more affected in the crisis than the North of Europe and also with the larger reliance of corporations to bank finance in the South of Europe.

We argue that our findings support the following story as a description of what eventually contributed to the 2009 investment collapse. The reduced market access of banks after the Lehman bankruptcy in September 2008 lead to a reduction in loan supply and increased lending standards. Bank-dependent borrowers could not costlessly substitute bank debt with other types of debt. As a result bank-dependent borrowers reduced investment spending more than other borrowers. This lead to a deep drop in investment spending in 2009. The remained of the paper is structured as following. In section two we present related literature. In section three we present the database. In section four we explain how we test for the credit channel effects. Section five presents the regression specification. Section six shows the estimation results and section seven concludes.

\section{Related literature}

A large macroeconomics literature investigates the role of credit-market imperfections and the role banks play for the propagation of shocks. In some respects the involvement of banks in the latest euro area recession is reminiscent of the Great depression of the 1930's. As an explanation of the magnitude of output loss during the Great depression, Bernanke (1983) has argued that shocks to the banking system propagated to the real economy and increased the depth of the Great depression. Essentially, Bernanke argues that due to shocks to the intermediation process of banks, certain borrowers faced a credit squeeze. With respect to the recent crisis, the evidence that banks reduced credit supply is accumulating. For instance, Ivashina and Scharfstein (2010) provide evidence on the syndicated loan market for the US. They show that banks reduced substantially lending in the syndicated loan market. They find that banks that relied more on deposits as a more stable sources of finance during the recent crisis, saw lending being reduced less. Similarly, a study using Portuguese bank lending data during the crisis, by Iyer et al.(2010) finds 
that banks that rely more on interbank lending as a source of finance reduce their lending more than banks that rely on other source of funding.

Incomplete and imperfect financial markets imply that certain borrowers, such as small firms, rely more on bank finance than others. They should therefore be more affected by a reduction in bank loan supply. Gertler and Gilchrist (1993) provide evidence that a large class of borrowers, especially small firms have difficulty in substituting bank debt. Therefore, in a crisis, small firms should see their spending drop the most. Chava and Purnanandam (2011) provide evidence of corporate behavior after the shock to the banking system from the Russian crisis in the Fall of 1998. They show that firms that financed themselves primarily with bank credit had higher stock market valuation losses, and suffered larger declines in investment than firms that had access to public debt markets. In the recent financial crisis, Iyer et al.(2010) show for Portuguese banks that smaller, younger firms are being supplied with less credit.

In particular, the recent financial crisis has generated renewed interest in how imperfection in financial markets spill over to the real economy. This paper aims to contribute the growing literature that investigates the real effects of the financial crisis on corporate behavior in general. Most evidence stems from the United states. Campello, Graham and Harvey (2010) survey 1050 Chief Financial Officers from 39 countries in the fourth quarter of 2008. They ask the CFOs' whether the firms were financially constrained. Their finding suggest that financially constrained firms are planning to cut spending more than non-financially constrained firms.

Using another survey of CFOs in a set of twin papers (one for the US and one for Europe) Campello et al. (2011a and 2011b) investigate how firms used credit lines during the financial crisis. They find that the ability to draw on credit lines eased the effect of the crisis on real spending. Almeida et al. (2009) show that firms whose long-term debt matured during the financial crisis observed larger drops in investment spending, consistent with a credit supply shock. A different perspective of the crisis is given by Kahle and Stulz (2011), which argue, based on quarterly financial statements of U.S. public firms around the crisis, that demand shocks and a rise in uncertainty were the major culprits of the drop in real spending, rather than a credit supply shock. However their data is restricted to public firms. Therefore it does not provide evidence on private firms which might be affected more by credit supply as they have likely a lower access to external finance.

Our study complements the above studies, as it adds to the understanding of the financial crisis along a number of dimensions. First we focus on the effect of 'bank' borrowing by corporations. As the credit supply shock in Europe mainly stems from banks we argue that this is a relevant path to analyze. Further, our evidence is not based 
on surveys as in Campello et al. (2010) and Campello et al. (2011a and 2011b), but is based on the actual outcomes during the crisis. We use aggregated balance sheet and profit and loss account data (including a statement of investment). Planned investment which is captured by surveys and actual investment which is captured by accounting data can differ. Further, due to the much longer time span of our series, we are able to compare investment behavior as it relates to bank borrowing with earlier periods. This provides an additional check whether bank debt had different effects in the current crisis, and the degree to which this is the case. Also, the cross-country nature allows to check if there are important cross-country differences.

This paper also brings new evidence to an earlier literature (Cantor, 1990; Sharpe, 1994; Calomiris et al 1994; $\mathrm{Hu}$ 1994) that investigates the role of leverage for corporate spending and the business cycle.

\section{The database}

or our study we used data coming from the European Commission BACH-database, for the period 2000-2009. The BACH-database is constructed through the aggregation of a large number of individual firms' annual balance sheets and profit and loss accounts. Aggregated firm balance sheets and profit and loss accounts are constructed per country and per year for three firm size classes and for different industries (NACE 2 digits). In our paper we include only the countries for which we have a sufficiently long panel of data: Germany, France, Italy, Spain, Belgium and Portugal.

In this paper we focus on the 24 manufacturing industries available in BACH (See Appendix for details). Each industry within a particular country has therefore three time series: one for small firms, one for medium firms and one for large firms. Firm size used for aggregation has been defined according to net turnover, with small firms having a turnover of less than 10 million euro, medium firms having a turnover from 10 million euro to 50 million and large firms having a turnover over 50 millions euro.

Usually, the number of firms used in the aggregation differs from year to year but in general it is quite large. A unit of observation is thus defined by size, industry and country (e.g. small firms in the textile industry in Germany). We follow these units over the period 2000-2009. After cleaning the data for outliers we have 351 cross-section units $(\mathrm{N})$ or a total of 2784 observations ( $\mathrm{N}$ times $\mathrm{T}$ ). For simplicity, in our paper we will refer to our cross-section units of observations as "firms".

The data is harmonized across countries so that balance sheet items and profit and loss account items have the same meaning (as much as possible) across countries. ${ }^{3}$ Using data

\footnotetext{
${ }^{3}$ The providers of the data harmonize the national firm accounting data ex-post. Firm financial
} 
that is aggregated up to the size-industry level has advantages and disadvantages. One disadvantage is a possible aggregation bias in which individual differences might disappear. If some firms are bank dependent and some are not in a particular industry-firm size class we might not find the effects back in the aggregate. The advantage however is that idiosyncratic noise is aggregated away and that average behavior of industries, relevant for macro-analysis is likely to become more prominent. Therefore if we find effects of bank credit, they are likely relevant from a macro-perspective.

Important for our purpose is that the balance sheet data makes a distinction between bank debt (called "Amounts owed to credit institutions"), trade debt (called "Trade creditors") and other debt. Although the balance sheet information does not allow us to know the exact source of "other debt". Thus other debt can technically include all other sources of debt such as debt from friends and family, debt from affiliated enterprises, liabilities to tax and social security authorities or market debt.

\section{Testing the role of bank debt during the financial crisis}

In this paper we use the year 2009 as our financial crisis year, which is the year related to the collapse in investment. One of our main questions is whether bank lending was a propagating factor in the collapse in investment in 2009. We further aim to distinguish the effect of bank lending from a general financial accelerator story, where it is shocks to firm nets worth that lead to endogenous movements in agency costs and leads to real effects on spending.

As our balance sheet data ranges from 2000 to 2009, we can also use information from before the financial crisis. Importantly, we can check whether bank or total debt are important determinants of investment during other periods as well. This provides a way to compare effects across periods. This sets our study apart from e.g. Campello et al. (2010) which uses a one-time survey on CFOs during the crisis. To exploit this earlier information we distinguish between three different episodes in the business cycle of a country. The first are periods of aggregate investment growth (nation-wide), which generally coincide with boom years, in our study they will be called investment boom years. The second are years in which aggregate investment drops but does not collapse (which we call investment downturns). The third is the year 2009; during that year in the midst of the financial crisis, investment dropped massively in all of the countries. For

accounting is being harmonized at the European level. However full harmonization has not yet been achieved and national accounting practices still differ to some degree. We however don't believe this to be a serious issue for our study. In any case we use country-level time fixed effects and individual fixed effects in our regressions. 
all countries in our study we thus divide the period 2001-2009 into three periods: boom, downturn, crisis. (The year 2000 is only used for lagged variables). For instance Spain had investment boom years from 2001 to 2007, an investment downturn in 2008 and a collapse in 2009. Germany had investment boom years from 2005 to 2008, investment downturn years from 2001 to 2004 and a collapse in 2009.

Table 1 summarizes the average annual growth in aggregate fixed capital formation (from national accounts data) during investment booms, downturns and the collapse year 2009. In all countries (except Belgium) the investment collapse of 2009 lead to a drop in investment more than three times the average drop during usual downturn years.

TABLE 1

\section{Aggregate fixed capital formation}

in investment booms, downturns and collapse year 2009

(Average annual growth: period 2001-2009)

\begin{tabular}{lccc}
\hline \hline & Boom & Downturn & Financial crisis Collapse \\
\hline Belgium & 3.74 & -4.46 & -8.11 \\
France & 3.25 & -1.95 & -9.04 \\
Germany & 3.85 & -2.71 & -11.41 \\
Italy & 2.44 & -2.50 & -11.74 \\
Portugal & 1.62 & -2.41 & -11.27 \\
Spain & 5.41 & -4.76 & -15.96 \\
Boom years: Belgium ('01,'03, '04,'05, '06, '07, '08), France('01,'03, '04, '05, '06, '07, '08), \\
Germany ('05,'06,'07,'08), Italy('01,'02,'04,'05, '06,'07),Portugal ('01,'07), \\
Spain('01,'02,'03,'04,'05,'06,'07) \\
Collapse year is 2009 for all countries
\end{tabular}

Source: own calculations based on EUROSTAT national accounts

Our investigation of the role of bank debt during the financial crisis is based on four tests. First we test whether bank debt leverage matters negatively for investment (controlling for total leverage) during the investment collapse of 2009. This is a necessary condition for bank debt to be important for investment. But it is not sufficient. Potentially bank debt always matters. A finding that it mattered in 2009 would than not indicate that the financial crisis was special. The time dimension of our panel here gives us additional information to tease out how special bank debt is. In a second and third test we check whether bank debt matters more during 2009 than during investment booms and during usual investment downturns. Finding evidence for this 'stronger' behavior we will interpret as evidence of a credit-channel operating through bank debt in 2009. Our fourth test allows us to check whether bank debt is special relative to other debt and therefore aims at separating financial accelerator effects from bank lending channel effects 
- There we test whether total leverage matters at all for investment in 2009, holding bank debt leverage constant.

The fourth test should allow us to distinguish between two possibly complementary, still distinct propagation mechanism stories of the financial crisis. One mechanism puts bank balance sheets and bank credit at the center. The other puts firms balance sheets at the center. The first mechanism, the bank lending channel when it has severe effects has been called a credit crunch. Bernanke and Lown (1991) have defined a bank credit crunch as "a significant leftward shift in the supply curve for bank loans, holding constant both the safe real interest rate and the quality of potential borrowers." Important here is that in Bernanke and Lown's definition the quality of borrowers remains constant. The shift is entirely due to the banks themselves. Such a leftward shift could come from a worsening of bank balance sheets. As stated before, the evidence pointing towards banks reducing lending after the Lehman event is mounting (See e.g. Ivashina and Scharfstein (2010)) After all, the financial crisis has also been called a banking crisis. As the banking crisis evolved (and slowly turned into a banking-sovereign debt crisis later on in the euro-area) and banks were faced with increased demands to increase their capital, banks reduced lending to shrunk their balance sheet. Under this scenario, firms that are bank dependent would suffer the most reduction in loan supply and would have to reduce spending.

An alternative, story is that in a recessionary environment, collateral values of borrowers fall and creditors increase financing premiums based on the weak balance sheets of borrowers. In this story, banks are just one type of creditor and are not behaving differently than other creditors. Banks would increase financing premiums on bank dependent borrowers with weak balance sheets. Markets would increase premiums on market financed firms with weak balance sheets. Highly leveraged firms are certainly one candidate of being financially vulnerable. Borrowers with weak balance sheets experience reduced access to credit. Under this scenario, lending might drop, but the reason is the borrowers balance sheet. This channel has been called the financial accelerator (Bernanke et al. (1996)). A financial accelerator mechanism can be caused by endogenous changes in the agency cost of lending. Weak balance sheets of borrowers are the main propagation mechanism.

Obviously, both channels can operate simultaneously and one does not exclude the other. Indeed it is quite likely that in a recessionary period during a banking crisis both operate simultaneously. However we will argue that the relative strength of both channels should be observable through the correlation of firms spending with different balance sheet variables. If a general financial accelerator is operative, outside of a banking crisis, we should see highly leveraged firms reduce investment, no matter where debt originates. As firms become highly leveraged, their lending to collateral ratio shrinks and therefore 
these firms are likely faced with a higher financing premium. In our paper, we focus on leverage as it is a direct indicator of debt capacity which should be linked to the external finance premium firms have to pay. In the financial accelerator story, there is a general flight to quality, and although bank debt is allowed to be special, there is no need for it to be special for the story to hold. Firms that are highly leveraged, be it from bank debt or other debt should see access to finance dwindle when a general financial accelerator is operating.

In a banking crisis however, banks are reducing credit supply because of banking problems. In a pure banking crisis it is firms that are levered with bank debt, that is now in restricted supply, that are effected. Especially those firms that cannot easily substitute bank debt with other debt should reduce spending. Firms that do not rely on bank debt or firms that can easily substitute away from bank debt should not see spending affected. We expect therefore that in a banking crisis, a credit supply reduction should have an effect on firms investment spending through its bank debt leverage, not through its total leverage.

\section{Bank debt, total leverage and the level of invest- ment}

\subsection{Specification}

To test for the different effect of bank or total leverage on investment spending during the three different episodes in the business cycle, we introduce two dummy variables. The dummy variable $R_{j t}$ captures investment downturn years (excluding the year of investment collapse 2009). It is equal to 1 in country $\mathrm{j}$ if aggregate fixed capital formation growth is negative in country $\mathrm{j}$, it is zero otherwise (we also set it at zero for all countries in the year 2009 , the investment collapse year). The dummy variable $C_{j t}$, controlling for the crisis year in country $\mathrm{j}$ is set to 1 in the year 2009 for all countries, and 0 otherwise. Controlling for the different effect of bank and total leverage during investment downturns and the financial crisis year 2009 we use the following specification to test for the importance of bank debt, 


$$
\begin{aligned}
\text { Investment }_{i t} / K_{i t}= & \alpha+\delta_{j t}+u_{i} \\
& +\beta \text { Investment }_{i, t-1} / K_{i t-1}+\gamma \text { Salesgrowth }_{i, t}+\lambda \text { Cashflow }_{i, t-1} / K_{i t-1} \\
& +\theta_{b} \text { Bank debt leverage }_{i, t-1}+\theta_{r} R_{j t} * \text { Bank debt leverage }_{i, t-1} \\
& +\theta_{c} C_{j t} * \text { Bank debt leverage }{ }_{i, t-1}+\rho_{b} \text { total leverage }_{i, t-1} \\
& +\rho_{r} R_{j t} * \text { total leverage }{ }_{i, t-1}+\rho_{c} * C_{j t} \text { total leverage }_{i, t-1}+\epsilon_{i, t}
\end{aligned}
$$

where Investment ${ }_{i t} / K_{i t}$ is the investment-rate of firm i at time $\mathrm{t}$ (i.e. investment capital ratio), sales growth $h_{i t}$ is sales growth at time t, Cashflow $w_{i t-1} / K_{i t-1}$ is the cash flow capital ratio at time t-1, Bank debt leverage $e_{i, t-1}$ is the bank debt leverage measure at (the end of) time $\mathrm{t}-1$, total leverage $e_{i, t-1}$ is the total financial leverage measure at (the end of) time t-1. (For more detail about the construction of the variables see the Appendix.) $\delta_{j t}$ is a country $\mathrm{j}$ time t fixed effect, $u_{i}$ is an unobserved firm fixed effect, and $\epsilon_{i, t}$ is a serially uncorrelated error term which is also uncorrelated with all variables at time $t-1$ but potentially correlated with variables at time $t$. As is customary, to allow for serial correlation in investment due to installation and adjustment lags we include lagged investment in the regression. Leverage variables are lagged one period with respect to investment to capture the state of the firm balance sheet at beginning of the investment period. We want to make sure that our lagged leverage variables don't just proxy lagged cash flow effects. So we add lagged cash flow as is customary in the financing constraints literature (Fazzari and Petersen (1988)). This should make finding leverage effects more difficult. Further we add contemporaneous sales growth to capture accelerator effects. We include country-time fixed effects to capture aggregate business cycle effects per country and include firm fixed effects to allow different average levels for all the variables.

Total leverage, total leverage $e_{i, t-1}$, is defined as total book value of debt (including bank debt but excluding trade debt) on total book value of assets (excluding trade debt). Trade debt is likely not a source of investment finance. In addition, trade debt is used in quite different degree among industries and countries. Because of these reasons, Rajan and Zingales (1995) argue in favor of a leverage measure excluding trade credit in comparative exercises. Bank debt leverage, Bank debt leverage ${ }_{i, t-1}$, is defined as book value of bank debt on total book value of assets (excluding trade debt).

We apply the same denominator in both types of leverage. The numerators only differ in the sense that total leverage includes all other types of debt besides bank debt. An increase in bank debt, all else equal, will therefore also increase total leverage unless the bank debt is used to substitute for other types of debt. This has to be kept in mind for the interpretation of the coefficients of this regression. 
The coefficient on bank debt leverage $\theta_{b}$ measures the effect on the investment rate of having higher bank leverage, holding total leverage constant. In other words it measures the effect on investment of substituting bank debt for other debt. The coefficients $\theta_{r}$ and $\theta_{c}$ measure the additional effect during downturn years and during 2009 respectively. Therefore, the total effect of substituting bank debt for other debt in boom years, downturns and 2009 is given respectively by $\theta_{b}, \theta_{b}+\theta_{r}$ and $\theta_{b}+\theta_{c}$.

Similarly the effect of having higher total leverage, holding bank debt leverage constant, in boom years is given by $\rho_{b}$. The coefficients $\rho_{r}$ and $\rho_{c}$ measure the additional effect during downturn years and during 2009 respectively. The total effect of having higher total leverage, holding bank debt leverage constant, in boom years, downturns and 2009 is given respectively by $\rho_{b}, \rho_{b}+\rho_{r}$ and $\rho_{b}+\rho_{c}$.

Our four tests can now be translated in terms of hypothesis tests on the coefficient estimates of this regression.

Hypothesis 1: Firms that financed themselves with more bank debt, (i.e. had higher bank debt leverage, at the start of 2009, for a given amount of total leverage), reduced investment more during the investment collapse of 2009. We test whether $\theta_{b}+\theta_{c}$ is negative.

Hypothesis 2: The same level of bank debt leverage, holding total leverage constant, leads to larger reduced investment during 2009 than during investment booms. This tests whether bank debt matters more during 2009 than during investment booms (controlling for total leverage). We test whether $\theta_{c}$ is negative.

Hypothesis 3: The same level of bank debt leverage, holding total leverage constant, leads to larger reduced investment during 2009 than during normal investment downturns. We test whether $\theta_{c}<\theta_{r}$.

Hypothesis 4: During the investment collapse of 2009, controlling for the level of bank debt leverage, total leverage had no effect on the investment of firms. We test whether $\rho_{b}+\rho_{c}$ is equal to zero. Effectively this tests whether a higher leverage (holding bank debt constant) also had negative effects on investment.

Hypothesis test 1 is clearly the most crucial one. If we find that firms that financed themselves with more bank debt, (i.e. had higher bank debt leverage, holding total leverage constant), reduced investment more in 2009 we can conclude that more bankdependent borrowers reduced investment more. Our test of the bank credit crunch benefits of having a time series of observations both during and outside the financial crisis so that we cannot only compare the effect on investment of the substitution of bank debt for other debt "within" the financial crisis (hypothesis 1), but also the effect on investment of bank debt "across" different time periods (hypothesis 2 and 3). 
Furthermore as the data allows us to distinguish between different sizes of firms we can also compare different effects across different size classes of firms. For that we split the sample into small, medium and large firms. We expect small and medium sized firms to be more affected by a credit crunch than large firms. If this is the case, $\theta_{b}+\theta_{c}$ should be larger (in absolute value terms) for small and medium sized firms than for large firms.

\subsection{Estimation}

There are three issues that need to be taken into account when estimating equation (1), namely the fixed effect, the presence of lagged investment and potential endogeneity.

Sales growth a time $t$ is likely endogenous with respect to investment. We assume that cash flow at time t- 1 and the leverage variables at time $\mathrm{t}-1$ are predetermined, i.e. uncorrelated with the error term at time t, but potentially correlated with the error terms of t-1 and earlier. It is well known that the presence of the lagged dependent variable leads to biased estimates for the traditional 'within' estimator (i.e. OLS on the deviations from the mean), as it introduces all past errors into the transformed error term (Nickel, 1981).

The standard way of estimating dynamic panel regressions with fixed effects, endogenous and predetermined variables is by the use of the generalized method of moments (GMM). This is the method we will use in our estimation. The literature uses two different GMM estimators: the difference GMM and the system GMM estimator.

Arellano and Bond (1991) introduced the first difference GMM estimator. Here lagged levels of the variables are used as instruments for the differenced equation. Where the differencing gets rid of the fixed effect, the lagged instruments take care of the endogeneity. The Arellano-Bond difference GMM estimator uses the following linear moments:

$$
E\left[\left(\epsilon_{i, t}-\epsilon_{i, t-1}\right) Z_{i, t-j}\right]=0 j=2,3, \ldots t=2001, \ldots, 2009
$$

where $Z_{i, t-j}$ is any of the following variables: Investment ${ }_{i t-j} / K_{i t-j}$, Salesgrowt $_{i, t-j}$, Cashflow $_{i, t-j} / K_{t-j}$, Bank debt leverage $e_{i, t-j}$ and total debt leverage ${ }_{i, t-j}$. Note the timing. Variables lagged twice are used as instruments for the first-differenced equation.

Arellano and Bover (1995) and Blundell and Bond (1998) propose in addition to use the lagged first differences of the variables as instruments for the level equation. Basically, they propose to use the following linear moment restrictions:

$$
E\left[\epsilon_{i, t} \triangle Z_{i, t-j}\right]=0 j=1,2, \ldots, t=2001, \ldots 2009
$$


This leads to a system-GMM estimator which uses both the moment conditions in (2) and (3). As this system estimator uses more moments, it leads to more efficient estimates.

However, Roodman (2009) has warned for overfitting in dynamic panel estimation when a large number of instruments is available. Using too many instruments can cause two type of problems. First, it can bias results towards ordinary least squares results. Second it tends to weaken specification tests. One specification test used in dynamic panel GMM estimation is the Hansen-test of overidentifying restrictions (Hansen, 1982). For instance, using many instruments can make the Hansen-test severly undersized. Using too many instruments can even lead to p-values that are arbitrarily close to one. Roodman (2009) suggests to test for robustness by reducing the instrument set to check whether the p-values of the Hansen test do not drop below critical values as the instrument set is reduced. To avoid overfitting problems, we therefore perform to actions. We present both results for system and first difference GMM (too many instruments are particularly a problem in system GMM as difference GMM uses far fewer instruments). Second we also present results when reducing the number of lags used as instruments. This follows the practice advocated by Roodman (2009) who shows results for reductions in the instrument set. We make sure that in those reduced instrument set regressions the number of instruments used in each estimation always stays quite substantially below the cross-section size of the panel, a criterion used to avoid overfitting discussed in Roodman (2009).

The validity of the instruments depends on the absence of serial correlation in the error term $\epsilon_{i t}$. Arellano and Bond (1991) develop test statistics to test first order and second order correlation of first differenced residuals. If the errors $\epsilon_{i t}$ are serially uncorrelated, than the differenced residuals should have no second order correlation (i.e. $\left(\epsilon_{i, t}-\epsilon_{i, t-1}\right)$ should be uncorrelated with $\left.\left(\epsilon_{i, t-2}-\epsilon_{i, t-3}\right)\right)$. We present the test statistic for second order correlation. ${ }^{4}$

\section{Estimation results}

\subsection{Results on total sample}

In this section we present the basic results on the total sample. Table 2 provides summary statistics of investment, sales growth, cash flow and the leverage variables for the total sample, and for the small, medium and large firms separately. The average bank debt leverage in the sample is 19.70 percent, however with a large dispersion between a minimum of 1.22 percent and a maximum of 43.46 percent. Size is correlated with bank-dependence. The average bank leverage is larger for small firms (23.86 pct) then for

\footnotetext{
${ }^{4}$ All estimations are performed using the stata program xtabond 2 written by Roodman.
} 
medium (20.66 pct) and large firms (13.78 pct), indicating their higher bank dependence. Small firms are also having a larger total financial leverage (50.68 pct) versus 46.38 pct for medium and 44.12 for large firms. Small firms also invest more, at a rate of 23.87 pct versus 21.68 for medium and 20.14 for large firms, while simultaneously they have lower cash flows 25.69 pct versus 32.45 for medium and 39.84 for large firms. Therefore it seems that given their higher dependence on bank debt and higher indebtedness overall, their higher rates of investment and lower cash flows, small firms should be the most vulnerable when a credit supply shocks hits.

TABLE 2

Summary statistics of the regression variables

\begin{tabular}{|c|c|c|c|c|c|}
\hline Variable & MEAN & ST.DEV & MEDIAN & 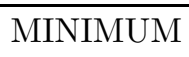 & MAXIMUM \\
\hline \multicolumn{6}{|l|}{ Total sample } \\
\hline Investment $_{i t} / K_{i t}$ & 21.87 & 12.23 & 20.89 & -17.76 & 60.29 \\
\hline Sales growth $_{i t}$ & 0.40 & 8.53 & 0.70 & -48.00 & 32.02 \\
\hline Cashflow $_{i t-1} / K_{i t-1}$ & 32.21 & 21.71 & 27.49 & -17.28 & 141.92 \\
\hline bank debt leverage ${ }_{i t-1}$ & 19.70 & 10.08 & 19.04 & 1.22 & 43.46 \\
\hline total leverage $_{i t-1}$ & 47.26 & 9.12 & 47.80 & 19.06 & 73.74 \\
\hline \multicolumn{6}{|l|}{ Small firms } \\
\hline Investment $_{i t} / K_{i t}$ & 23.87 & 12.67 & 23.91 & -16.72 & 59.93 \\
\hline Sales growth $_{i t}$ & 0.36 & 7.82 & 0.64 & -38.03 & 32.02 \\
\hline Cashflow $_{i t-1} / K_{i t-1}$ & 25.69 & 18.85 & 20.98 & -12.23 & 132.35 \\
\hline bank debt leverage ${ }_{i t-1}$ & 23.86 & 8.94 & 24.20 & 3.03 & 43.46 \\
\hline total leverage $_{i t-1}$ & 50.68 & 7.86 & 50.92 & 19.55 & 73.09 \\
\hline \multicolumn{6}{|l|}{ Medium firms } \\
\hline Investment $_{i t} / K_{i t}$ & 21.68 & 11.94 & 19.92 & -16.93 & 60.29 \\
\hline Sales growth ${ }_{i t}$ & 0.34 & 6.18 & 0.61 & -38.03 & 25.66 \\
\hline Cashflow $_{i t-1} / K_{i t-1}$ & 32.45 & 18.35 & 28.75 & -16.65 & 122.84 \\
\hline bank debt leverage $i t-1$ & 20.66 & 9.38 & 19.66 & 1.44 & 43.05 \\
\hline total leverage $_{i t-1}$ & 46.38 & 7.97 & 46.78 & 19.08 & 72.83 \\
\hline \multicolumn{6}{|l|}{ Large firms } \\
\hline Investment $_{i t} / K_{i t}$ & 20.14 & 11.84 & 18.68 & -17.76 & 60.08 \\
\hline Sales growth ${ }_{i t}$ & 0.51 & 11.08 & 1.00 & -48.00 & 31.93 \\
\hline Cashflow $_{i t-1} / K_{i t-1}$ & 39.84 & 25.42 & 33.88 & -17.28 & 141.92 \\
\hline bank debt leverage $_{i t-1}$ & 13.78 & 9.23 & 11.89 & 1.22 & 43.00 \\
\hline total leverage $_{i t-1}$ & 44.12 & 10.25 & 43.82 & 19.06 & 73.74 \\
\hline
\end{tabular}

Notes: Numbers in percentages

Source: Own calculations 
TABLE 3

The effect of total and bank debt leverage on investment over the business cycle and during the financial crisis: full sample

\begin{tabular}{|c|c|c|c|c|c|}
\hline \multicolumn{6}{|c|}{$\begin{array}{l}\text { Dependent variable is } \text { Investment }_{i t} / K_{i t} \\
\text { System and difference GMM estimates }\end{array}$} \\
\hline \multirow[b]{2}{*}{ Variable } & & (1) & (2) & (3) & $(4)$ \\
\hline & coeff. & SYS-GMM & SYS-GMM & DIFF-GMM & DIFF-GMM \\
\hline \multirow[t]{2}{*}{ Investment $_{i t-1} / K_{i t-1}$} & $\beta$ & $0.25^{* * *}$ & $0.25^{* * *}$ & $0.20^{* * *}$ & $0.21^{* * *}$ \\
\hline & & $(0.03)$ & $(0.04)$ & $(0.04)$ & $(0.04)$ \\
\hline \multirow[t]{2}{*}{ Sales growth } & $\gamma$ & 0.02 & 0.08 & $0.10^{*}$ & $0.22^{* *}$ \\
\hline & & $(0.04)$ & $(0.05)$ & $(0.06)$ & $(0.08)$ \\
\hline \multirow[t]{2}{*}{ Cashflow $_{i t-1} / K_{i t-1}$} & $\lambda$ & $0.07^{* * *}$ & $0.05^{* * *}$ & $0.12^{* * *}$ & $0.10^{* *}$ \\
\hline & & $(0.02)$ & $(0.02)$ & $(0.03)$ & $(0.04)$ \\
\hline \multirow[t]{2}{*}{ bank debt leverage $_{i t-1}$} & $\theta_{b}$ & 0.04 & -0.006 & -0.18 & -0.05 \\
\hline & & $(0.06)$ & $(0.07)$ & $(0.12)$ & $(0.14)$ \\
\hline \multirow[t]{2}{*}{$R_{j t}{ }^{*}$ bank debt leverage ${ }_{i t-1}$} & $\theta_{r}$ & -0.08 & -0.07 & -0.05 & -0.001 \\
\hline & & $(0.08)$ & $(0.08)$ & $(0.08)$ & $(0.09)$ \\
\hline \multirow[t]{2}{*}{$C_{j t}{ }^{*}$ bank debt leverage $e_{i t-1}$} & $\theta_{c}$ & $-0.25^{* * *}$ & $-0.22^{* * *}$ & $-0.29^{* * *}$ & $-0.34^{* * *}$ \\
\hline & & $(0.08)$ & $(0.08)$ & $(0.11)$ & $(0.12)$ \\
\hline \multirow{2}{*}{ total leverage $e_{i t-1}$} & $\rho_{b}$ & $0.10^{*}$ & 0.07 & $0.20^{* *}$ & 0.15 \\
\hline & & $(0.05)$ & $(0.06)$ & $(0.09)$ & $(0.10)$ \\
\hline \multirow[t]{2}{*}{$R_{j t}{ }^{*}$ total leverage ${ }_{i t-1}$} & $\rho_{r}$ & -0.10 & -0.08 & -0.14 & -0.07 \\
\hline & & $(0.09)$ & $(0.10)$ & $(0.11)$ & $(0.13)$ \\
\hline \multirow[t]{2}{*}{$C_{j t}{ }^{*}$ total leverage $i t-1$} & $\rho_{c}$ & -0.12 & -0.15 & -0.10 & 0.15 \\
\hline & & $(0.09)$ & $(0.09)$ & $(0.14)$ & $(0.16)$ \\
\hline Number of Observations & & 2784 & 2784 & 2784 & 2784 \\
\hline \multicolumn{2}{|l|}{ Cross-section } & 351 & 351 & 351 & 351 \\
\hline \multicolumn{2}{|l|}{ Number of Instruments } & 414 & 264 & 234 & 159 \\
\hline \multicolumn{2}{|l|}{ m2 (p-value) } & 0.31 & 0.38 & 0.66 & 0.75 \\
\hline \multicolumn{2}{|l|}{ H-test (p-value) } & 0.97 & 0.14 & 0.33 & 0.53 \\
\hline \multicolumn{2}{|l|}{ diff H-test (p-value) } & 1.00 & 0.13 & - & - \\
\hline \multicolumn{6}{|l|}{ Notes: Sample period is $2000-2009$} \\
\hline \multicolumn{6}{|c|}{$R_{j t}$ downturn year dummy equal to 1 in 2001-04 for Germany, 2002 for France, 2002 for Belgium, } \\
\hline \multicolumn{6}{|c|}{2003 and 2008 for Italy, 2008 for Spain, 2002-06 and 2008 for Portugal. $C_{j t}$ equal to 1 in 2009 for all countries. } \\
\hline \multicolumn{6}{|c|}{ Each regression includes country-time dummies, and constant term } \\
\hline \multicolumn{6}{|c|}{ Standard errors are heteroscedasticity consistent using Windmeijer (2005) correction } \\
\hline \multicolumn{6}{|c|}{ Columns (1) and (3) include all lags of instruments, columns (2) and (4) include 3 lags of instruments, } \\
\hline \multicolumn{6}{|c|}{$\mathrm{m} 2$ is second order serial correlation tests, asymptotically $\mathrm{N}(0,1)$} \\
\hline \multicolumn{6}{|c|}{ H-test is Hansen test: asymptotically $\chi_{351}^{2}, \chi_{201}^{2}, \chi_{171}^{2}$ and $\chi_{96}^{2}$ for cols (1) to (4) } \\
\hline \multicolumn{6}{|c|}{ diff-H-test is difference test for validity of the additional instruments in system GMM } \\
\hline$* * *$ Significant at $1 \%$ level, $* *$ a & $5 \%$ leve & at $10 \%$ level & & & \\
\hline
\end{tabular}

Table 3 shows the estimation results of our basic regression using the full sample. Columns 1 and 2 show the system GMM estimates using respectively all lags and three 
lags as instruments. Column 3 and 4 show the difference GMM results using all and three lags respectively. The test statistics of all four estimation results suggests there are no problems with the specification or with the instruments. For all regressions we can safely reject second order serial correlation of the first differenced residuals. Also the Hansen test does not reject the null hypothesis of validity of the instrument set for all the results. However, note that in the case of the system GMM, the Hansen test p-value drops dramatically from 0.97 for the regression using all instruments to 0.14 for the regression using only three lags as instruments. As discussed in Roodman (2009), this indicates potential problems with system GMM. Further the difference Hansen test which test the validity of the additional first difference instruments for the level equation in system GMM has a p-value of only 0.13. Although the validity of these instruments is not rejected at conventional significance levels, our preferred results are based on the difference GMM estimates (column (3) and (4)). For the difference GMM estimates, a reduction in the instrument set does not lead to a reduction in the p-value of the Hansen test below critical values. On the contrary the p-value even increases. Note that as we reduce the instrument set in difference GMM, coefficient estimates are slightly less precise, which should be expected.

Except where we state otherwise, our discussion that follows is based on results in column (4). Note however that estimation results are very similar across all regressions. The regression seems to be well specified. Lagged investment is highly significant, as expected, and has a positive coefficient. Sales growth has a positive effect on investment, as expected. Also cash flow is significantly positive. Although this could indicate the presence of financing constraints, a different interpretation is also possible, namely that cash flow proxies for profitability and therefore investment opportunities.

Of the six coefficients on leverage only one is significantly different from zero. The coefficient $\theta_{c}$ which measures the additional effect of bank leverage during 2009, has a negative sign and is significantly different from zero at the 1 percent level. Our first hypothesis that firms that financed themselves with more bank debt, reduced investment more during the investment collapse of 2009 is confirmed. The point estimate of the total effect of bank debt leverage in $2009 \theta_{b}+\theta_{c}$ is equal to -0.38 (with a standard error of 0.19 ) which is significantly different from zero at the 5 pct level. So the estimation results confirm that firms that financed themselves with more bank debt, i.e. had higher bank debt leverage, at the start of 2009, for a given amount of total leverage, reduced investment more during the investment collapse of 2009. The effect is quite substantial. A one standard deviation increase in the bank debt leverage ratio (i.e. 10 percentage points), holding total leverage constant, leads to a reduction in investment of 3.8 percentage points. The average investment rate is 21.9 percent over the sample period, so this effect is quite 
economically substantial. A firm at the 25th percentile in our sample has a bank debt leverage ratio of 11.42 compared with 27.73 for a firm at the 75 percentile. The regression results indicate a difference in the investment rate of 6.20 percentage points.

In contrast, bank debt leverage does not have an effect during boom years. The coefficient $\theta_{b}$ is statistically insignificant indicating that bank leverage has no effect on investment during boom years. Also we find no effect during downturn years, $\theta_{b}+\theta_{r}$ is estimated to -0.05 (with a standard error of 0.14 ), insignificantly different from zero. Therefore our second and third hypothesis, which stated that the same level of bank debt leverage leads to larger effects in 2009 than in earlier booms and earlier downturns, are both confirmed. Only during the financial crisis did bank debt leverage become important.

The evidence also points towards a bank credit crunch and not a financial accelerator story. Namely, we have a statistically non-significant effect of total financial leverage, i.e. we cannot reject that $\rho_{b}, \rho_{r}$ and $\rho_{c}$ are all zero. Also the total effect $\rho_{b}+\rho_{r}$ and $\rho_{b}+\rho_{c}$ are insignificantly different from zero ( they are respectively estimated to be 0.08 with a standard error of 0.15 and 0.31 with a standard error of 0.20$)$. This result is in striking contrast with the significance of bank debt leverage. In 2009 it was bank debt leverage that mattered for investment not total financial leverage.

To sum it up, the results in table 3 strongly suggest that increased bank leverage had a negative effect on investment in 2009. Higher total financial leverage, holding bank debt constant, however did not effect investment negatively. Taking together this evidence is strongly suggestive that bank credit was important during 2009 and suggests more the effect of banks reducing supply of loans rather than pure balance sheet effects of firms in reducing investment.

\subsection{Results by size}

This section presents results according to firm size. If there was a flight to quality in 2009 we should observe that smaller firms are more affected than larger firms. Gertler and Gilchrist (1993) show that credit flows to small and large firms differ after monetary tightening. Whereas bank lending to large firms increases substantially, it only increases slightly for small firms. The data allows to split the sample into small, medium and large firms. The estimation results are presented in Table 4.

The sample splitting comes at a serious costs, namely the number of cross section observations gets reduced from 351 in the total sample to 111 for the small firms, 123 for the medium sized firms and 117 for the large firms. We also present results for small

and medium sided firms pooled together which increase the number of the cross section to 234. Following Roodman (2009), which states that the number of instruments have to less than the number of cross-section observations to avoid overfitting, we reduce the number 
of instrument lags accordingly. In columns (1), (2) and (3) we present the difference GMM results using only one lag of the instruments for small, medium and large firms respectively. Columns (4) and (5) present the small and medium firms pooled results for system and difference GMM, using 2 lags of instruments.

Due to the reduced sample sizes the estimates for small, medium and large firms separately lead to imprecise estimates. Interestingly is the exception of the cash flow coefficients which are significant for all three size classes but are largest for small firms, and lowest for the large firms. This confirms traditional findings in the literature (Fazzari, Hubbard and Petersen (1988) and Gertler and Hubbard (1988)) that uses cash flow sensitivity as a measure of constraints and shows that small firms have higher cash flow sensitivities which is interpreted as evidence that these firms are more likely to face liquidity constraints. ${ }^{5}$

The bank debt leverage variables for small, medium and large firms separately are estimated rather imprecisely. The point estimate $\theta_{c}$ of the small firms is -0.39 larger (in absolute terms) than the point estimate of the medium sized firms -0.30 and especially the large firms -0.03. However in all cases it is imprecisely estimated and not statistically different from zero. The total effect of bank debt leverage during 2009, $\theta_{b}+\theta_{c}$, is estimated to be -0.90 (with a standard error of 0.84 ) for the small firms, -0.03 (with a standard error of 0.33 ) for the medium sized firms and -0.01 (with a standard error of 0.25 ) for the large firms. The pooled results of small and medium sized firms confirm our earlier results. $\theta_{c}$ is significantly negative both for system and difference GMM. And the total effect of bank debt leverage during 2009 is estimated to be -0.47 (s.e. of 0.19 ) for the system GMM and -0.28 (s.e. of 0.22 ). These estimates strongly suggest that small firms were the most vulnerable, confirming our assumptions.

\footnotetext{
${ }^{5}$ For a critique on the cash flow sensitivity literature see Kaplan and Zingales (1997).
} 
TABLE 4

The effect of financial and bank leverage on investment

over the business cycle and during the financial crisis: according to size

\begin{tabular}{|c|c|c|c|c|c|c|}
\hline \multicolumn{7}{|c|}{$\begin{array}{l}\text { Dependent variable is } \text { Investment }_{i t} / K_{i t} \\
\text { System and difference GMM estimates }\end{array}$} \\
\hline \multirow[b]{2}{*}{ Variable } & \multirow[b]{2}{*}{ coeff. } & (1) & (2) & $(3)$ & $(4)$ & $(5)$ \\
\hline & & $\begin{array}{l}\text { SMALL } \\
\text { DIFF-GMM }\end{array}$ & $\begin{array}{l}\text { MEDIUM } \\
\text { DIFF-GMM }\end{array}$ & $\begin{array}{c}\text { LARGE } \\
\text { DIFF-GMM }\end{array}$ & $\begin{array}{l}\text { SMALL/MED. } \\
\text { SYS-GMM }\end{array}$ & $\begin{array}{l}\text { SMALL/MED. } \\
\text { DIFF-GMM }\end{array}$ \\
\hline \multirow[t]{2}{*}{ Investment $_{i t-1} / K_{i t-1}$} & $\beta$ & 0.12 & 0.07 & 0.16 & $0.19^{* * *}$ & $0.14^{* * *}$ \\
\hline & & $(0.11)$ & $(0.07)$ & $(0.13)$ & $(0.04)$ & $(0.05)$ \\
\hline \multirow[t]{2}{*}{ Sales growth } & $\gamma$ & 0.08 & 0.02 & 0.14 & -0.02 & 0.02 \\
\hline & & $(0.12)$ & $(0.19)$ & $(0.14)$ & $(0.07)$ & $(0.09)$ \\
\hline \multirow{2}{*}{ Cashflow $_{i t-1} / K_{i t-1}$} & $\lambda$ & $0.25^{* *}$ & $0.15^{* *}$ & 0.07 & $0.08^{* * *}$ & $0.11^{* *}$ \\
\hline & & $(0.12)$ & $(0.08)$ & $(0.06)$ & $(0.03)$ & $(0.06)$ \\
\hline \multirow[t]{2}{*}{ bank debt leverage ${ }_{i t-1}$} & $\theta_{b}$ & $-0.51^{*}$ & 0.27 & 0.02 & -0.06 & 0.0009 \\
\hline & & $(0.30)$ & $(0.23)$ & $(0.21)$ & $(0.09)$ & $(0.16)$ \\
\hline \multirow{2}{*}{$R_{j t} *$ bank debt leverage $e_{i t-1}$} & $\theta_{r}$ & 0.25 & 0.05 & -0.07 & 0.01 & -0.02 \\
\hline & & $(0.23)$ & $(0.25)$ & $(0.15)$ & $(0.13)$ & $(0.14)$ \\
\hline \multirow[t]{2}{*}{$C_{j t} *$ bank debt leverage $e_{i t-1}$} & $\theta_{c}$ & -0.39 & -0.30 & -0.03 & $-0.40^{* *}$ & $-0.28^{* *}$ \\
\hline & & $(0.70)$ & $(0.25)$ & $(0.18)$ & $(0.17)$ & $(0.14)$ \\
\hline \multirow[t]{2}{*}{ total leverage $e_{i t-1}$} & $\rho_{b}$ & $0.60^{* *}$ & -0.29 & 0.09 & $0.13^{*}$ & -0.01 \\
\hline & & $(0.20)$ & $(0.20)$ & $(0.29)$ & $(0.07)$ & $(0.11)$ \\
\hline \multirow[t]{2}{*}{$R_{j t}{ }^{*}$ total leverage $i t-1$} & $\rho_{r}$ & -0.39 & 0.05 & -0.51 & -0.01 & 0.08 \\
\hline & & $(0.26)$ & $(0.30)$ & $(0.33)$ & $(0.13)$ & $(0.12)$ \\
\hline \multirow[t]{2}{*}{$C_{j t}{ }^{*}$ total leverage ${ }_{i t-1}$} & $\rho_{c}$ & 0.67 & 0.003 & 0.27 & 0.002 & 0.14 \\
\hline & & $(0.67)$ & $(0.36)$ & $(0.37)$ & $(0.16)$ & $(0.22)$ \\
\hline \multicolumn{2}{|l|}{ Number of observations } & 905 & 997 & 882 & 1902 & 1902 \\
\hline \multicolumn{2}{|l|}{ Cross section } & 111 & 123 & 117 & 234 & 234 \\
\hline \multicolumn{2}{|l|}{ Number of instruments } & 84 & 94 & 94 & 204 & 129 \\
\hline \multicolumn{2}{|l|}{$\mathrm{m} 2(\mathrm{p}$-value $)$} & 0.52 & 0.33 & 0.63 & 0.24 & 0.49 \\
\hline \multicolumn{2}{|l|}{ H-test (p-value) } & 0.59 & 0.40 & 0.19 & 0.23 & 0.09 \\
\hline \multicolumn{2}{|l|}{ diff H-test (p-value) } & - & - & - & 0.56 & - \\
\hline \multicolumn{7}{|l|}{ Notes: Sample period is $2000-2009$} \\
\hline \multicolumn{7}{|c|}{$R_{j t}$ downturn year dummy equal to 1 in 2001-04 for Germany, 2002 for France, 2002 for Belgium, } \\
\hline \multicolumn{7}{|c|}{2003 and 2008 for Italy, 2008 for Spain, 2002-06 and 2008 for Portugal. $C_{j t}$ equal to 1 in 2009 for all countries. } \\
\hline \multicolumn{7}{|c|}{ Each regression includes country-time dummies, and constant term } \\
\hline \multicolumn{7}{|c|}{ Standard errors are heteroscedasticity consistent using Windmeijer (2005) correction } \\
\hline \multicolumn{7}{|c|}{ columns (1),(2) and (3) include 1 lag of instruments, columns (4) and (5)include 2 lags of instruments, } \\
\hline \multicolumn{7}{|c|}{$\mathrm{m} 2$ is second order serial correlation tests,asymptotically $\mathrm{N}(0,1)$} \\
\hline \multicolumn{7}{|c|}{$\mathrm{H}$ is Hansen test: asymptotically $\chi_{31}^{2}$ for columns $(1),(2)$ and (3), $\chi_{141}^{2}$ for column (4), $\chi_{66}^{2}$ for column (5) } \\
\hline *** Significant at $1 \%$ level, ${ }^{* *}$ at & $5 \%$ level & * at $10 \%$ level & & & & \\
\hline
\end{tabular}




\subsection{Country sensitivity and splitting sample North-South}

As our data spans six countries, it is natural to ask whether bank debt leverage mattered equally across countries in 2009? Unfortunately as the results in Table 4 with sample splitting shows, we cannot split our total cross-section sample of 351 firms into too small subsamples, as this leads to imprecise estimates. In this section however we try to find out more about potential asymmetric effects of the credit crunch. First we check whether results might be driven by one country only. For that we replicate the basic regressions of Table 3, but now for only 5 countries together, i.e. dropping 1 country at a time. Dropping 1 country reduces the sample size to about 300 firms. We present both result for system-GMM and for difference GMM.

Table 5 presents the results of all possible five-country combinations for system GMM. All results use 3 lags of the instruments. The coefficient estimate of $\theta_{c}$ remains significant at least at the 10 percent level no matter which country we drop from the sample. Interesting however the point estimate becomes smaller (in absolute terms) and less precise when we drop either Spain, Portugal or Italy, countries from the so-called "South" of Europe. Qualitative similar results hold for the difference GMM estimates in Table 6.

Importantly in the South of Europe firms rely more on bank debt than in the North of Europe. In our sample average bank debt leverage is 11.75 in France, 15.56 in Belgium, 18.88 in Germany, 19.89 in Portugal, 22.88 in Spain and 29.87 in Italy. As we cannot test countries individually we can test whether firms in the North of Europe were equally affected as firms in the South. This reduces our sample further to 191 for the North versus 160 for the south. Table 7 presents the results of this sample split. The results are quite striking. The coefficient $\theta_{c}$ is insignificant in the North but significant and with a point estimate between -0.31 for system GMM versus - 0.37 for difference GMM quite large in absolute terms. Together these findings suggest that a credit crunch had asymmetric effect in Europe, where the South was affected while the North was not. 
TABLE 5

The effect of financial and bank leverage on investment

over the business cycle and during the financial crisis: different country sets

(dropping 1 country at a time: system GMM baseline model)

\begin{tabular}{|c|c|c|c|c|c|c|c|}
\hline \multicolumn{8}{|c|}{ Dependent variable is Investment $_{i t} / K_{i t}$} \\
\hline Variable & coeff. & Germany & $\begin{array}{l}\text { Country } \\
\text { France }\end{array}$ & $\begin{array}{l}\text { excluded } \\
\text { Italy }\end{array}$ & Spain & Belgium & Portugal \\
\hline \multirow[t]{2}{*}{ Investment $_{i t-1} / K_{i t-1}$} & $\bar{\beta}$ & $0.25^{* * *}$ & $0.25^{* * *}$ & $0.25^{* * *}$ & $0.25^{* * *}$ & $0.26^{* * *}$ & $0.25^{* * *}$ \\
\hline & & $(0.04)$ & $(0.04)$ & $(0.04)$ & $(0.04)$ & $(0.04)$ & $(0.04)$ \\
\hline \multirow{2}{*}{ Sales growth it $_{1}$} & $\gamma$ & 0.07 & 0.05 & 0.07 & 0.06 & $0.13^{* * *}$ & -0.05 \\
\hline & & $(0.05)$ & $(0.05)$ & $(0.06)$ & $(0.06)$ & $(0.05)$ & $(0.05)$ \\
\hline \multirow[t]{2}{*}{ Cashflow $_{i t-1} / K_{i t-1}$} & $\lambda$ & $0.04^{* *}$ & $0.07^{* * *}$ & $0.05^{* *}$ & $0.06^{* * *}$ & $0.07^{* * *}$ & $0.07^{* * *}$ \\
\hline & & $(0.02)$ & $(0.02)$ & $(0.02)$ & $(0.02)$ & $(0.02)$ & $(0.02)$ \\
\hline \multirow[t]{2}{*}{ bank debt leverage lit-1 } & $\theta_{b}$ & -0.09 & 0.04 & 0.03 & -0.03 & 0.07 & 0.07 \\
\hline & & $(0.07)$ & $(0.07)$ & $(0.08)$ & $(0.08)$ & $(0.08)$ & $(0.07)$ \\
\hline \multirow[t]{2}{*}{$R_{j t} *$ bank debt leverage ${ }_{i t-1}$} & $\theta_{r}$ & -0.09 & -0.10 & -0.04 & -0.03 & -0.05 & -0.05 \\
\hline & & $(0.08)$ & $(0.08)$ & $(0.09)$ & $(0.08)$ & $(0.08)$ & $(0.08)$ \\
\hline \multirow[t]{2}{*}{$C_{j t} *$ bank debt leverage ${ }_{i t-1}$} & $\theta_{c}$ & $-0.26^{* *}$ & $-0.25^{* * *}$ & $-0.21^{*}$ & $-0.14^{*}$ & $-0.24^{* *}$ & $-0.18^{*}$ \\
\hline & & $(0.09)$ & $(0.08)$ & $(0.11)$ & $(0.08)$ & $(0.10)$ & $(0.10)$ \\
\hline \multirow[t]{2}{*}{ total leverage $_{i t-1}$} & $\rho_{b}$ & 0.06 & 0.06 & 0.07 & 0.06 & 0.09 & 0.09 \\
\hline & & $(0.05)$ & $(0.06)$ & $(0.06)$ & $(0.05)$ & $(0.07)$ & $(0.06)$ \\
\hline \multirow[t]{2}{*}{$R_{j t}{ }^{*}$ total leverage $i t-1$} & $\rho_{r}$ & -0.09 & -0.09 & -0.09 & -0.03 & -0.06 & -0.07 \\
\hline & & $(0.09)$ & $(0.11)$ & $(0.10)$ & $(0.10)$ & $(0.11)$ & $(0.11)$ \\
\hline \multirow[t]{2}{*}{$C_{j t}{ }^{*}$ total leverage $i t-1$} & $\rho_{c}$ & -0.12 & -0.11 & -0.15 & -0.06 & -0.14 & -0.09 \\
\hline & & $(0.11)$ & $(0.09)$ & $(0.12)$ & $(0.10)$ & $(0.12)$ & $(0.12)$ \\
\hline \multicolumn{2}{|l|}{ Number of observations } & 2284 & 2210 & 2398 & 2327 & 2283 & 2418 \\
\hline \multicolumn{2}{|l|}{ Cross section } & 291 & 282 & 305 & 291 & 289 & 297 \\
\hline \multicolumn{2}{|l|}{ Number of instruments } & 255 & 255 & 255 & 255 & 255 & 255 \\
\hline \multicolumn{2}{|l|}{$\mathrm{m} 2(\mathrm{p}$-value $)$} & 0.08 & 0.89 & 0.34 & 0.24 & 0.81 & 0.36 \\
\hline \multicolumn{2}{|l|}{ H-test (p-value) } & 0.27 & 0.16 & 0.28 & 0.43 & 0.32 & 0.04 \\
\hline \multicolumn{2}{|l|}{ diff H-test (p-value) } & 0.29 & 0.19 & 0.34 & 0.66 & 0.15 & 0.10 \\
\hline \multicolumn{8}{|l|}{ Notes: Sample period is $2000-2009$} \\
\hline \multicolumn{8}{|c|}{$R_{j t}$ downturn year dummy equal to 1 in 2001-04 for Germany, 2002 for France, 2002 for Belgium, } \\
\hline \multicolumn{8}{|c|}{2003 and 2008 for Italy, 2008 for Spain, 2002-06 and 2008 for Portugal. $C_{j t}$ equal to 1 in 2009 for all countries. } \\
\hline Each regression includes country & time dur & mies, and con & tant term & & & & \\
\hline Standard errors are heteroscedas & icity con & stent using $\mathrm{V}$ & indmeijer $(20$ & 5) correction & & & \\
\hline All regressions use 3 lags of inst & uments, & & & & & & \\
\hline $\mathrm{m} 2$ is second order serial correla & on tests & symptotically & $\mathrm{N}(0,1)$ & & & & \\
\hline H-test is Hansen test: asymptot & ally $\chi_{20}^{2}$ & & & & & & \\
\hline diff-H-test is difference test,asyn & t. $\chi_{105}^{2}$ & $y$ & 1. & . & & & \\
\hline *** Significant at $1 \%$ level, $* *$ & leve & at $10 \%$ leve & & & & & \\
\hline
\end{tabular}


TABLE 6

The effect of financial and bank leverage on investment

over the business cycle and during the financial crisis: different country sets

(dropping 1 country at a time: difference GMM baseline model)

Dependent variable is Investment $t_{i t} / K_{i t}$

Country excluded

$\begin{array}{lllll}(1) & (2) & (3) & (4) & (5)\end{array}$

\begin{tabular}{|c|c|c|c|c|c|c|c|}
\hline Variable & coeff. & Germany & France & Italy & Spain & Belgium & Portugal \\
\hline \multirow[t]{2}{*}{ Investment $_{i t-1} / K_{i t-1}$} & $\bar{\beta}$ & $0.19^{* * *}$ & $0.23^{* * *}$ & $0.20^{* * *}$ & $0.20^{* * *}$ & $0.22^{* * *}$ & $0.22^{* * *}$ \\
\hline & & $(0.05)$ & $(0.05)$ & $(0.05)$ & $(0.05)$ & $(0.04)$ & $(0.04)$ \\
\hline \multirow{2}{*}{ Sales growth $_{i t}$} & $\gamma$ & $0.20^{* *}$ & $0.15^{*}$ & $0.17^{*}$ & $0.14^{*}$ & $0.28^{* *}$ & 0.09 \\
\hline & & $(0.07)$ & $(0.08)$ & $(0.09)$ & $(0.08)$ & $(0.08)$ & $(0.07)$ \\
\hline \multirow[t]{2}{*}{ Cashflow $_{i t-1} / K_{i t-1}$} & $\lambda$ & $0.08^{* *}$ & $0.10^{* *}$ & $0.08^{*}$ & $0.09^{* *}$ & $0.11^{* *}$ & $0.11^{* *}$ \\
\hline & & $(0.04)$ & $(0.05)$ & $(0.05)$ & $(0.04)$ & $(0.04)$ & $(0.04)$ \\
\hline \multirow[t]{2}{*}{ bank debt leverage $e_{i t-1}$} & $\theta_{b}$ & -0.25 & 0.03 & -0.005 & -0.07 & 0.07 & -0.29 \\
\hline & & $(0.15)$ & $(0.14)$ & $(0.14)$ & $(0.16)$ & $(0.19)$ & $(0.14)$ \\
\hline \multirow[t]{2}{*}{$R_{j t}$ bank debt leverage ${ }_{i t-1}$} & $\theta_{r}$ & $-0.04^{* *}$ & -0.05 & 0.05 & 0.04 & 0.03 & -0.09 \\
\hline & & $(0.09)$ & $(0.10)$ & $(0.11)$ & $(0.10)$ & $(0.10)$ & $(0.10)$ \\
\hline \multirow[t]{2}{*}{$C_{j t}$ bank debt leverage $e_{i t-1}$} & $\theta_{c}$ & $-0.37^{* *}$ & $-0.32^{* *}$ & $-0.25^{*}$ & -0.13 & $-0.39^{* *}$ & $-0.32^{* *}$ \\
\hline & & $(0.13)$ & $(0.13)$ & $(0.14)$ & $(0.10)$ & $(0.14)$ & $(0.12)$ \\
\hline \multirow{2}{*}{ total leverage $e_{i t-1}$} & $\rho_{b}$ & 0.08 & -0.007 & 0.16 & 0.12 & 0.20 & 0.17 \\
\hline & & $(0.11)$ & $(0.11)$ & $(0.11)$ & $(0.10)$ & $(0.14)$ & $(0.11)$ \\
\hline \multirow[t]{2}{*}{$R_{j t}{ }^{*}$ total leverage ${ }_{i t-1}$} & $\rho_{r}$ & -0.02 & -0.04 & -0.15 & -0.12 & -0.04 & -0.07 \\
\hline & & $(0.13)$ & $(0.16)$ & $(0.14)$ & $(0.14)$ & $(0.15)$ & $(0.13)$ \\
\hline \multirow[t]{2}{*}{$C_{j t}{ }^{*}$ total leverage $i t-1$} & $\rho_{c}$ & 0.04 & 0.13 & 0.06 & 0.14 & 0.14 & 0.11 \\
\hline & & $(0.14)$ & $(0.16)$ & $(0.17)$ & $(0.17)$ & $(0.16)$ & $(0.20)$ \\
\hline Number of Observations & & 2284 & 2210 & 2398 & 2327 & 2283 & 2418 \\
\hline Cross section & & 291 & 282 & 305 & 291 & 289 & 297 \\
\hline Number of Instruments & & 150 & 150 & 150 & 150 & 150 & 150 \\
\hline $\mathrm{m} 2$ (p-value) & & 0.21 & 0.95 & 0.64 & 0.59 & 0.64 & 0.70 \\
\hline H-test (p-value) & & 0.45 & 0.32 & 0.31 & 0.24 & 0.80 & 0.20 \\
\hline
\end{tabular}

Sample period is 2000-2009

$R_{j t}$ downturn year dummy equal to 1 in 2001-04 for Germany, 2002 for France, 2002 for Belgium,

2003 and 2008 for Italy, 2008 for Spain, 2002-06 and 2008 for Portugal. $C_{j t}$ equal to 1 in 2009 for all countries.

Each regression includes country-time dummies, and constant term

Standard errors are heteroscedasticity consistent using Windmeijer (2005) correction

$\mathrm{m} 2$ is second order serial correlation tests,asymptotically $\mathrm{N}(0,1)$

*** Significant at $1 \%$ level, ** at $5 \%$ level, * at $1 \%$ level 
TABLE 7

The effect of financial and bank leverage on investment over the business cycle and during the financial crisis: North versus South Europe

\begin{tabular}{|c|c|c|c|c|c|}
\hline \multicolumn{6}{|c|}{$\begin{array}{l}\text { Dependent variable is } \text { Investment }{ }_{i t} / K_{i t} \\
\text { System and difference GMM estimates }\end{array}$} \\
\hline \multirow[b]{3}{*}{ Variable } & \multirow[b]{3}{*}{ coeff. } & \multirow{3}{*}{$\begin{array}{c}(1) \\
\text { North } \\
\text { SYS-GMM }\end{array}$} & \multirow{3}{*}{$\begin{array}{c}(2) \\
\text { North } \\
\text { DIFF-GMM }\end{array}$} & \multirow{3}{*}{$\begin{array}{c}(3) \\
\text { South } \\
\text { SYS-GMM }\end{array}$} & \multirow{3}{*}{$\begin{array}{l}(4) \\
\text { South } \\
\text { DIFF-GMM }\end{array}$} \\
\hline & & & & & \\
\hline & & & & & \\
\hline \multirow[t]{2}{*}{ Investment $_{i t-1} / K_{i t-1}$} & $\beta$ & $0.21^{* * *}$ & $0.20^{* * *}$ & $0.22^{* * *}$ & $0.14^{* *}$ \\
\hline & & $(0.07)$ & $(0.06)$ & $(0.05)$ & $(0.07)$ \\
\hline \multirow[t]{2}{*}{ 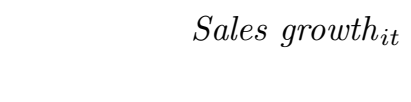 } & $\gamma$ & -0.05 & -0.06 & $0.14^{*}$ & $0.14^{* *}$ \\
\hline & & $(0.12)$ & $(0.08)$ & $(0.07)$ & $(0.07)$ \\
\hline \multirow{2}{*}{ Cashflow $_{i t-1} / K_{i t-1}$} & $\lambda$ & $0.07^{* *}$ & $0.10^{* *}$ & $0.07^{* *}$ & $0.18^{* * *}$ \\
\hline & & $(0.03)$ & $(0.04)$ & $(0.03)$ & $(0.05)$ \\
\hline \multirow[t]{2}{*}{ bank debt leverage ${ }_{i t-1}$} & $\theta_{b}$ & 0.13 & 0.13 & $0.20^{*}$ & -0.12 \\
\hline & & $(0.14)$ & $(0.21)$ & $(0.10)$ & $(0.20)$ \\
\hline \multirow{2}{*}{$R_{j t} *$ bank debt leverage ${ }_{i t-1}$} & $\theta_{r}$ & -0.03 & -0.05 & 0.05 & -0.009 \\
\hline & & $(0.13)$ & $(0.14)$ & $(0.08)$ & $(0.08)$ \\
\hline \multirow[t]{2}{*}{$C_{j t} *$ bank debt leverage $e_{i t-1}$} & $\theta_{c}$ & -0.15 & -0.03 & $-0.31^{* * *}$ & $-0.37^{* *}$ \\
\hline & & $(0.15)$ & $(0.17)$ & $(0.11)$ & $(0.15)$ \\
\hline \multirow[t]{2}{*}{ total leverage $_{i t-1}$} & $\rho_{b}$ & 0.15 & $0.24^{* *}$ & 0.03 & 0.12 \\
\hline & & $(0.10)$ & $(0.12)$ & $(0.10)$ & $(0.16)$ \\
\hline \multirow[t]{2}{*}{$R_{j t}{ }^{*}$ total leverage $i t-1$} & $\rho_{r}$ & -0.04 & -0.10 & $-0.24^{* *}$ & -0.17 \\
\hline & & $(0.17)$ & $(0.16)$ & $(0.11)$ & $(0.11)$ \\
\hline \multirow[t]{2}{*}{$C_{j t}{ }^{*}$ total leverage $e_{i t-1}$} & $\rho_{c}$ & 0.13 & 0.12 & -0.02 & -0.10 \\
\hline & & $(0.16)$ & $(0.21)$ & $(0.14)$ & $(0.15)$ \\
\hline \multicolumn{2}{|l|}{ Number of Observations } & 1575 & 1575 & 1209 & 1209 \\
\hline \multicolumn{2}{|l|}{ Cross section } & 191 & 191 & 160 & 160 \\
\hline \multicolumn{2}{|l|}{ Number of Instruments } & 107 & 132 & 107 & 132 \\
\hline \multicolumn{2}{|l|}{$\mathrm{m} 2(\mathrm{p}$-value $)$} & 0.43 & 0.49 & 0.82 & 0.50 \\
\hline \multicolumn{2}{|l|}{ H-test (p-value) } & 0.07 & 0.13 & 0.67 & 0.17 \\
\hline \multicolumn{2}{|l|}{ diff $\mathrm{H}$-test ( $\mathrm{p}$-value) } & 0.19 & - & 0.42 & - \\
\hline \multicolumn{6}{|l|}{ Notes: Sample period is $2000-2009$} \\
\hline \multicolumn{6}{|c|}{$R_{j t}$ downturn year dummy equal to 1 in 2001-04 for Germany, 2002 for France, 2002 for Belgium, } \\
\hline \multicolumn{6}{|c|}{2003 and 2008 for Italy, 2008 for Spain, 2002-06 and 2008 for Portugal. $C_{j t}$ equal to 1 in 2009 for all countries. } \\
\hline \multicolumn{6}{|c|}{ Each regression includes country-time dummies, and constant term } \\
\hline \multicolumn{6}{|c|}{ Standard errors are heteroscedasticity consistent using Windmeijer(2005) correction } \\
\hline columns (1) and (3) include one & ag of ins & ments, columns & and (4) include 3 & ss of instrument & \\
\hline $\mathrm{m} 2$ is second order serial correla & ion tests & mptotically $\mathrm{N}($ & & & \\
\hline H-test is Hansen test: asymptoti & ally $\chi_{71}^{2}$ & $6, \chi_{71}^{2}$ and $\chi_{96}^{2}$ & olumns (1)to (4) & & \\
\hline diff-H-test is difference test, asyr & pt $\chi_{40}^{2}$ & validity of the & ional instruments & system GMM & \\
\hline *** Significant at $1 \%$ level, $* *$ a & $5 \%$ leve & at $10 \%$ level & & & \\
\hline
\end{tabular}




\subsection{Further robustness checks}

In this section we provide some further robustness check to our basic results. It is possible that firms use past levels of cash as a buffer against credit supply shocks. In Table 8 we present results where we replace cash flow with the level of cash (as a fraction of total assets). As in our earlier results (Table 3), system GMM results show that the Hansen test p-value drops dramatically from 0.94 for the regression using all instruments to 0.19 for the regression using only three lags as instruments. In addition the difference H-test shows a clear rejection of the exogeneity of the additional instruments in system GMM. So our preferred results are again the difference GMM results (columns (3) and (4). Our main results remain standing. Cash is never significant and $\theta_{c}$ remains highly negative and significant. 
TABLE 8

The effect of financial and bank leverage on investment

over the business cycle and during the financial crisis: robustness using cash

(Replacing Cash flow with Cash )

\begin{tabular}{|c|c|c|c|c|c|}
\hline \multicolumn{6}{|c|}{$\begin{array}{l}\text { Dependent variable is } \text { Investment }{ }_{i t} / K_{i t} \\
\text { System and difference GMM estimates }\end{array}$} \\
\hline \multirow[b]{2}{*}{ Variable } & & (1) & $(2)$ & $(3)$ & $(4)$ \\
\hline & coeff. & SYS-GMM & SYS-GMM & DIFF-GMM & DIFF-GMM \\
\hline \multirow[t]{2}{*}{ Investment $_{i t-1} / K_{i t-1}$} & $\beta$ & $0.27^{* * *}$ & $0.26^{* * *}$ & $0.16^{* * *}$ & $0.20^{* * *}$ \\
\hline & & $(0.03)$ & $(0.03)$ & $(0.04)$ & $(0.04)$ \\
\hline \multirow[t]{2}{*}{ Sales growth ${ }_{i t}$} & $\gamma$ & 0.04 & 0.06 & $0.13^{* *}$ & $0.23^{* * *}$ \\
\hline & & $(0.04)$ & $(0.05)$ & $(0.05)$ & $(0.07)$ \\
\hline \multirow[t]{2}{*}{$C A S H_{i t-1}$} & $\lambda$ & 0.06 & 0.13 & -0.06 & 0.04 \\
\hline & & $(0.07)$ & $(0.08)$ & $(0.15)$ & $(0.23)$ \\
\hline \multirow[t]{2}{*}{ bank debt leverage ${ }_{i t-1}$} & $\theta_{b}$ & 0.02 & 0.03 & -0.05 & 0.12 \\
\hline & & $(0.07)$ & $(0.07)$ & $(0.13)$ & $(0.15)$ \\
\hline \multirow[t]{2}{*}{$R_{j t}{ }^{*}$ bank debt leverage $i t-1$} & $\theta_{r}$ & -0.07 & -0.07 & 0.01 & 0.02 \\
\hline & & $(0.08)$ & $(0.08)$ & $(0.08)$ & $(0.09)$ \\
\hline \multirow[t]{2}{*}{$C_{j t}{ }^{*}$ bank debt leverage $i t-1$} & $\theta_{c}$ & $-0.25^{* * *}$ & $-0.28^{* * *}$ & $-0.26^{* * *}$ & $-0.22^{* *}$ \\
\hline & & $(0.09)$ & $(0.09)$ & $(0.09)$ & $(0.10)$ \\
\hline \multirow[t]{2}{*}{ total leverage $_{i t-1}$} & $\rho_{b}$ & 0.03 & 0.04 & -0.04 & 0.03 \\
\hline & & $(0.05)$ & $(0.06)$ & $(0.10)$ & $(0.13)$ \\
\hline \multirow[t]{2}{*}{$R_{j t}{ }^{*}$ total leverage $i t-1$} & $\rho_{r}$ & -0.10 & -0.18 & $-0.23^{*}$ & $-0.25^{* *}$ \\
\hline & & $(0.10)$ & $(0.12)$ & $(0.13)$ & $(0.12)$ \\
\hline \multirow[t]{2}{*}{$C_{j t}{ }^{*}$ total leverage $e_{i t-1}$} & $\rho_{c}$ & -0.11 & -0.10 & -0.14 & -0.10 \\
\hline & & $(0.08)$ & $(0.10)$ & $(0.15)$ & $(0.14)$ \\
\hline \multicolumn{2}{|l|}{ Number of observations } & 2828 & 2828 & 2828 & 2828 \\
\hline \multicolumn{2}{|l|}{ Cross section } & 353 & 353 & 353 & 353 \\
\hline \multicolumn{2}{|l|}{ Number of instruments } & 414 & 264 & 24 & 159 \\
\hline \multicolumn{2}{|l|}{$m_{2}(\mathrm{p}$-value $)$} & 0.33 & 0.37 & 0.94 & 0.93 \\
\hline \multicolumn{2}{|l|}{ H-test (p-value) } & 0.94 & 0.19 & 0.24 & 0.78 \\
\hline \multicolumn{2}{|l|}{ diff H-test (p-value) } & 1.00 & 0.02 & - & - \\
\hline \multicolumn{6}{|l|}{ Notes: Sample period is $2000-2009$} \\
\hline \multicolumn{6}{|c|}{$R_{j t}$ downturn year dummy equal to 1 in 2001-04 for Germany, 2002 for France, 2002 for Belgium, } \\
\hline \multicolumn{6}{|c|}{2003 and 2008 for Italy, 2008 for Spain, 2002-06 and 2008 for Portugal. $C_{j t}$ equal to 1 in 2009 for all countries. } \\
\hline \multicolumn{6}{|c|}{ Each regression includes country-time dummies, and constant term } \\
\hline \multicolumn{6}{|c|}{ Standard errors are heteroscedasticity consistent using Windmeijer (2005) correction. } \\
\hline \multicolumn{6}{|c|}{ Columns (1) and (3) include all lags of instruments, columns (2) and (4) include 3 lags of instruments, } \\
\hline \multicolumn{6}{|c|}{$\mathrm{m} 2$ is second order serial correlation tests,asymptotically $\mathrm{N}(0,1)$} \\
\hline \multicolumn{6}{|c|}{ H-test is Hansen test: asymptotically $\chi_{351}^{2}, \chi_{201}^{2}, \chi_{171}^{2}$ and $\chi_{96}^{2}$ for cols (1) to (4) } \\
\hline \multicolumn{6}{|c|}{ diff-H-test is difference test for validity of the additional instruments in system GMM. Asympt. $\chi_{180}^{2}, \chi_{105}^{2}$ for cols (1)(2) } \\
\hline *** Significant at $1 \%$ level, ${ }^{* *}$ a & $5 \%$ leve & at $10 \%$ level & & & \\
\hline
\end{tabular}


Another possibility is that cash flow has different effects over the cycle, i.e. it is possible that firms used cash flow more intensively during the collapse of 2009 and that the interaction of the bank debt leverage with the crisis dummy $C_{j t}$ simply proxies for different cash flow usage in the crisis. We test this by interacting the cash flow variable with our downturn dummy $R_{j t}$ and collapse year dummy $C_{j t}$. Results are presented in Table 9 . We do not find a different sensitivity with cash flow over the business cycle. Again $\theta_{c}$ remains highly negative and significant and its magnitude barely changes. So cash flow effects are clearly different than leverage effects. 
TABLE 9

The effect of financial and bank leverage on investment

over the business cycle and during the financial crisis: different cash flow sensitivity

(Allowing different Cash flow effect during crisis )

\begin{tabular}{|c|c|c|c|c|c|}
\hline \multicolumn{6}{|c|}{$\begin{array}{l}\text { Dependent variable is Investment }{ }_{i t} / K_{i t} \\
\text { System and difference GMM estimates }\end{array}$} \\
\hline \multirow[b]{2}{*}{ Variable } & & $(1)$ & $(2)$ & (3) & $(4)$ \\
\hline & coeff. & SYS-GMM & SYS-GMM & DIFF-GMM & DIFF-GMM \\
\hline \multirow[t]{2}{*}{ Investment $_{i t-1} / K_{i t-1}$} & $\beta$ & $0.25^{* * *}$ & $0.25^{* * *}$ & $0.20^{* * *}$ & $0.21^{* * *}$ \\
\hline & & $(0.03)$ & $(0.04)$ & $(0.04)$ & $(0.04)$ \\
\hline \multirow[t]{2}{*}{ Sales growth } & $\gamma$ & 0.02 & 0.07 & $0.11^{*}$ & $0.22^{* * *}$ \\
\hline & & $(0.44)$ & $(0.05)$ & $(0.06)$ & $(0.08)$ \\
\hline \multirow[t]{2}{*}{ Cashflow $_{i t-1} / K_{i t-1}$} & $\lambda_{b}$ & $0.07^{* * *}$ & $0.05^{* * *}$ & $0.10^{* * *}$ & $0.10^{* *}$ \\
\hline & & $(0.02)$ & $(0.02)$ & $(0.03)$ & $(0.05)$ \\
\hline \multirow[t]{2}{*}{$R_{j t} *$ Cashflow $_{i t-1} / K_{i t-1}$} & $\lambda_{r}$ & 0.04 & 0.03 & 0.03 & -0.001 \\
\hline & & $(0.03)$ & $(0.03)$ & $(0.04)$ & $(0.05)$ \\
\hline \multirow{2}{*}{$C_{j t} *$ Cashflow $_{i t-1} / K_{i t-1}$} & $\lambda_{c}$ & -0.02 & -0.02 & -0.04 & 0.008 \\
\hline & & $(0.02)$ & $(0.03)$ & $(0.04)$ & $(0.06)$ \\
\hline \multirow[t]{2}{*}{ bank debt leverage $_{i t-1}$} & $\theta_{b}$ & 0.04 & -0.01 & -0.17 & -0.04 \\
\hline & & $(0.06)$ & $(0.07)$ & $(0.12)$ & $(0.14)$ \\
\hline \multirow[t]{2}{*}{$R_{t} *$ bank debt leverage $e_{i t-1}$} & $\theta_{r}$ & -0.08 & -0.07 & -0.02 & -0.005 \\
\hline & & $(0.08)$ & $(0.09)$ & $(0.08)$ & $(0.10)$ \\
\hline \multirow[t]{2}{*}{$C_{t}{ }^{*}$ bank debt leverage ${ }_{i t-1}$} & $\theta_{c}$ & $-0.24^{* * *}$ & $-0.24^{* * *}$ & $-0.30^{* * *}$ & $-0.33^{* * *}$ \\
\hline & & $(0.09)$ & $(0.09)$ & $(0.11)$ & $(0.13)$ \\
\hline \multirow[t]{2}{*}{ total leverage $e_{i t-1}$} & $\rho_{b}$ & $0.09^{*}$ & 0.07 & $0.18^{*}$ & 0.15 \\
\hline & & $(0.05)$ & $(0.05)$ & $(0.10)$ & $(0.10)$ \\
\hline \multirow[t]{2}{*}{$R_{j t}{ }_{\text {total leverage }}{ }_{i t-1}$} & $\rho_{r}$ & -0.05 & -0.04 & -0.10 & -0.07 \\
\hline & & $(0.10)$ & $(0.11)$ & $(0.12)$ & $(0.16)$ \\
\hline \multirow[t]{2}{*}{$C_{j t}{ }^{*}$ total leverage $e_{i t-1}$} & $\rho_{c}$ & -0.12 & -0.16 & -0.22 & 0.18 \\
\hline & & $(0.09)$ & $(0.10)$ & $(0.18)$ & $(0.26)$ \\
\hline \multicolumn{2}{|l|}{ Number of Observations } & 2784 & 2784 & 2784 & 2784 \\
\hline \multicolumn{2}{|l|}{ Cross section } & 351 & 351 & 351 & 351 \\
\hline \multicolumn{2}{|l|}{ Number of Instruments } & 414 & 264 & 234 & 159 \\
\hline \multicolumn{2}{|l|}{$m_{2}(\mathrm{p}$-value $)$} & 0.30 & 0.39 & 0.67 & 0.75 \\
\hline \multicolumn{2}{|l|}{ H-test (p-value) } & 0.98 & 0.10 & 0.31 & 0.47 \\
\hline \multicolumn{2}{|l|}{ diff H-test (p-value) } & 1.00 & 0.10 & - & - \\
\hline \multicolumn{6}{|l|}{ Sample period is $2000-2009$} \\
\hline \multicolumn{6}{|c|}{$R_{j t}$ downturn year dummy equal to 1 in 2001-04 for Germany, 2002 for France, 2002 for Belgium, } \\
\hline \multicolumn{6}{|c|}{2003 and 2008 for Italy, 2008 for Spain, 2002-06 and 2008 for Portugal. $C_{j t}$ equal to 1 in 2009 for all countries. } \\
\hline \multicolumn{6}{|c|}{ Each regression includes country-time dummies, and constant term } \\
\hline \multicolumn{6}{|c|}{ Standard errors are heteroscedasticity consistent using Windmeijer (2005) correction } \\
\hline \multicolumn{6}{|c|}{ H-test is Hansen test: asymptotically $\chi_{349}^{2}, \chi_{199}^{2}, \chi_{169}^{2}$ and $\chi_{94}^{2}$ for cols (1)to(4) } \\
\hline \multicolumn{6}{|c|}{ diff-H-test is difference test for validity of the additional instruments in system GMM. Asympt. $\chi_{180}^{2}, \chi_{105}^{2}$ for cols (1)(2) } \\
\hline $\mathrm{m} 2$ is second order serial correla & ion tests & mptotically $\mathrm{N}(0$, & & & \\
\hline$* * *$ Significant at $1 \%$ level, $* *$ a & $5 \%$ leve & at $10 \%$ level & & & \\
\hline
\end{tabular}


We also check robustness when we consider also 2008 as a crisis year. Although investment only collapsed in 2009. Quarterly data suggest that after the Lehman event aggregate output and investment dropped in fourth quarter of 2008 as well. In Table 10 our collapse dummy $C_{j t}$ is set equal to one for the year 2008 and 2009 (correspondingly the $R_{j t}$ dummy is set at zero for those two years). The qualitative results remain the same. The coefficient estimate of $\theta_{c}$ becomes smaller (in absolute terms). Suggesting that indeed the leverage effects become smaller when one considers the period 2008-2009 versus only the collapse year 2009. 


\section{Conclusion}

The financial crisis led to an unprecedented drop in aggregate fixed capital formation in 2009. The coincidence of a banking crisis with a recession makes the investigation of credit channel effects operating through bank debt more pertinent. We show that firms that entered 2009 with a higher bank debt leverage reduced investment substantially more than firms that entered with a lower bank debt leverage.

Importantly, throughout our entire estimation results we control for total leverage. Our results therefore indicate that bank debt caused real effects and not simply weak balance sheets on the side of firms. Our findings strongly suggest that a drop in supply of bank credit has been responsible. We find strong effects for small and medium sized firms and for the South of Europe, where firms are more bank-dependent. Our study has clear limitations. We used aggregate (two-digit) industry-level data, for three firm size classes, not individual firm level data. Important sources of heterogeneity might be aggregated away. Nevertheless, despite the level of aggregation, the fact that we find bank leverage to be important in 2009 underlines the importance of our findings for macro-economists. The effect of bank debt in financial crisis does not go away when one aggregates.

Our findings are in line with earlier evidence. Campello, Graham and Harvey (2010) have shown from surveys that CFOs declare that when they were financially constrained during the crisis that valuable investment opportunities were canceled. We have provided evidence using actual investment data that especially for firms that were bank-dependent investment was much lower during the crisis. Likely, this implies that profitable investment opportunities have been foregone.

The fact that bank-dependent firms are more affected than others has important implications for policy-makers. As the data shows us, a recession coinciding with a banking crisis can lead to a large output-loss. To the extent that the output loss takes the form of large investment cancelations, the future growth path is potentially affected. For policymakers this suggest that taking measures to shorten a banking crisis and restore credit flows seems to have first order effects on spending. 


\section{A APPENDIX}

\section{A.1 Construction of the sample}

The source of the data is the BACH-database from the European Commission. It contains annual aggregated balance sheet and profit and loss account information for different industries and size classes of firms. The sizes classes are defined as follows: small firms have sales less than 10 millions euro; medium firms have sales from 10 millions euro to 50 millions euro; large firms have sales over 50 millions euro.

Initially the 24 manufacturing industries (see A.3.) and 3 size classes for Germany, France, Italy, Spain, Belgium and Portugal where selected for the years 2000-2009. This gives a maximum 72 "representative firms" for each country (not all countries have all industries). The $1 \%$ outliers of the variables used in the regression are removed. This leads to a total of 351 "representative firms."

\section{A.2 Construction of the variables}

Investment ${ }_{i t} / K_{i t}$ : Investment capital ratio. Investment is measured as Acquisition of tangible fixed assets minus sales and disposals. Capital stock is measured by book value of fixed assets.

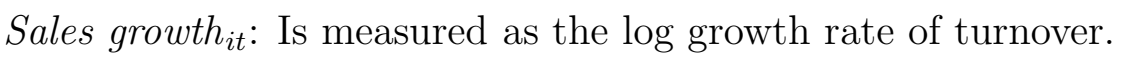

Cashflow $_{i t-1} / K_{i t-1}$ : Cash flow is measured as Gross operating profit minus Interest and similar charges minus Taxes on profits. Capital stock is measured by book value of fixed assets.

bank debt leverage $e_{i-1}$ : Amounts owed to credit institutions (amounts becoming due and payable within one year)+Amounts owed to credit institutions (amount becoming due and payable after more than one year) divided by "total assets minus trade creditors".

total leverage $e_{i-1}$ : Creditors: amounts becoming due and payable within one year plus Creditors: amount becoming due and payable after more than one year minus trade creditors divided by "total assets minus trade creditors)".

\section{A.3 List of the industries used}

The following industries are used.

10: Manufacture of food products 11: Manufacture of beverages 12: Manufacture of tobacco products 13: Manufacture of textiles 14: Manufacture of wearing apparel 15: Manufacture of leather and related products 16: Manufacture and production of wood and cork etc. 17: Manufacture of paper and paper products 18: Printing and reproduction of recorded media 19: Manufacture of coke and refined petroleum products 20: 
Manufacture of chemicals and chemical products 21: Manufacture of basic pharmaceutics products and pharmaceutics preparations 22: Manufacture of rubber and plastic products 23: Manufacture of other non-metallic mineral products 24: Manufacture of basic metals 25: Manufacture of fabrication metal products except machinery and equipment 26: Manufacture of computer, electronic and optical products 27: Manufacture of electrical equipment 28: Manufacture of machinery and equipment N.E.C 29: Manufacture of motor vehicles, trailers and semi-trailers 30: Manufacture of other transport equipment 31: Manufacture of furniture 32: Other manufacturing 33: Repair and installation of machinery and equipment 


\section{References}

[1] Almeida, Heitor, Murillo Campello, Bruno Laranjeira and Scott Weisbenner, "Corporate debt maturity and the real effects of the 2007 credit crisis",(2009), NBER Working Paper 14990.

[2] Arellano, Manuel and Stephen Bond, "Some tests of specification for Panel Data: Monte Carlo Evidence and an application to Employment Equations," Review of Economic Studies, 58 (1991): 277-297.

[3] Arellano, Manuel and Olympia Bover, "Another look at the instrumental variables estimation of error components models," Journal of Econometrics 68(1995):29-51

[4] Bernanke, Ben, "Nonmonetary Effects of the Financial crisis in the propagation of the great depression", The American Economic Review, June (1983): 257-276.

[5] Bernanke, Ben and Alan Blinder, "Credit, Money, and Aggregate Demand," American-Economic-Review 78 (May 1988): 435-439.

[6] Bernanke, Ben, Mark Gertler and Simon Gilchrist "The Financial accelerator and the flight to quality," The Review of Economics and Statistics 78 (February 1996): $1-15$.

[7] Bernanke, Ben and Cara S. Lown, "The Credit Crunch",Brookings Papers on Economic Activity No 2 (1991):205-247.

[8] Blundell R. and Stephen Bond, "Initial conditions and moment restrictions in dynamic panel data models," Journal of Econometrics 87(1998): 115-143.

[9] Brunnermeier, Markus, 2009, Deciphering the Liquidity and Credit Crunch 20072008 Journal of Economic Perspectives vol. 23(1), 77-100.

[10] Calomiris, Charles W., Athanasios Orphanides and Steven Sharpe, "Leverage as a state variable for employment, inventory accumulation, and fixed investment," NBER Working paper, 4800 (July 1994)

[11] Campello, Murillo, John R. Graham and Campell R. Harvey, "The real effects of financial constraints: Evidence from a financial crisis," Journal of Financial Economics (97) 470-487

[12] Campello, Murillo, Erasmo Giambona, John R. Graham and Campell R. Harvey, "Liquidity Management and Corporate Investment during a financial crisis," Review of financial studies (2011) 1944-1979 
[13] Campello, Murillo, John R. Graham and Campell R. Harvey, "Access to liquidity and corporate investment in Europe During the financial crisis," mimeo (2011)

[14] Cantor Richard, "Effects of Leverage on corporate investment and hiring decisions'," (1990),Federal Reserve Board New York Quarterly Review, Summer,31-41.

[15] Chava Sudheer and Amiyatosch Purnanandam, "The effect of banking crisis on bankdependent borrowers, Journal of Financial Econometrics 99 (2011): 116-135.

[16] Fazzari, Steven M., Glenn Hubbard and Bruce Petersen, "Financing Constraints and Corporate Investment," Brookings Papers on Economic Activity 1 (1988): 141-195.

[17] Gertler, Mark and Simon Gilchrist, "Monetary Policy, Business Cycles, and the Behavior of Small Manufacturing Firms," The Quarterly Journal of Economics 59 (May 1994): 309-340.

[18] Gertler, Mark and Simon Gilchrist, "The Role of Credit Market Imperfections in the Monetary Transmission Mechanism: Arguments and Evidence," Scandinavian Journal of Economics 95 (1993): 43-64.

[19] Gertler Mark and Glenn R. Hubbard, "Financial factors in business fluctutations," In Financial Market Volatility(1988), Kansas City: Federal reserve bank of Kansas city: 33-71.

[20] Hansen, L., "Large sample properties of generalized method of moments estimators",Econometrica 50,(1982): 1029-1054.

[21] Hu, Charles X., "Leverage, Monetary Policy, and Firm investment," Federal Reserve Bank of San Francisco Economic Review (2) (1999):32-39.

[22] Ivashina, Victoria and David Scharfstein, "Bank lending during the financial crisis of 2008," Journal of financial economics (97) (2010):319-338

[23] Iyer, Rajkamal, Samuel Lopes, José-Luis Peydró and Antoinette Schoar, "Interbank liquidity crunch and the firm credit crunch: evidence from the 2007-2009 crisis," mimeo.

[24] Kahle, Kathleen and René M. Stulz, "Financial policies, Investment, and the Financial crisis: Impaired credit channel or diminshed demand for capital?," Dice Center Working Paper (February 2011).

[25] Kaplan, Steven N. and Luigi Zingales, "Do investment cash-flow sensitivities provide useful measures of financing constraints?," The Quarterly Journal of Economics (February 1997): 169-215. 
[26] Nickell, Stephen, "Biases in Dynamic Models with fixed effects," Econometrica 49 (November 1981): 1417-1426.

[27] Rajan, Raghuram G. and Luigi Zingales, "What Do We Know about Capital Structure? Some Evidence from International Data," The Journal of Finance 50 (1995):1421-1460.

[28] Roodman, David, "A note on the theme of too many instruments," Oxford Bulletin of Economics and Statistics 71,(2009): 135-158.

[29] Sharpe, Steven, "Financial Market Imperfections, Firm Leverage, and the cyclicality of Employment," American Economic Review (September 1994):1060-1074.

[30] Windmeijer, Frank, "A finite sample correction for the variance of linear efficient two-step GMM estimators," Journal of Econometrics (May 2005):25-51. 